\title{
A REVIEW OF THE RELEVANCE OF DEMOGRAPHY TO AUSTRALIAN WATER PLANNING
}

\author{
Leonardo Carroll, ${ }^{\dagger}$ The Australian National University
}

\begin{abstract}
Australia is in the process of implementing a new and comprehensive agenda of water policy reform, notably under the National Water Initiative (NWI). National, regional and local water plans are crucial components of the water policy framework. Together with other disciplines, demography can make important contributions to the water planning process. Demography is clearly relevant to urban water supply planning. It is also relevant to national, State/Territory and regional water planning: for example, demographers can assist with understanding who is affected by water plans, who uses water, and who is likely to be affected by new water policy initiatives such as markets and trading.
\end{abstract}

Keywords: water, planning, environmental policy, population, demographic data, Australia

In Australia, the recent drought, water shortages, and the threat of climate change have put water management squarely at the top of the public agenda. Water managers aim to address the two fundamental concerns of water quantity and water quality (Smith 2003). They work with a complex kaleidoscope of water planning procedures and instruments (for an overview, see Gentle and Olszak 2007).

Water plans are made at many levels. Urban water supply planning, by local water utilities responsible for reticulated (piped) supply to citizens, has a long history. There is also a history of planning, by the colonies and later the states and territories, for irrigation and flood management. More recently, water planning has become a concern for other Commonwealth, state and regional authorities. A proliferation of Commonwealth, state/territory and regional institutions and frameworks has been established, to manage and account for water resources, notably under the National Water Initiative (NWI). Figure 1 illustrates three main levels at which water planning is undertaken in Australia: at a high level, by the Commonwealth, state and territory governments; at a regional, particularly catchment, level; and for individual urban centres.

Many studies have documented the theoretical links between water and population (Falkenmark and Widstrand 1992; Falkenmark et al. 1997; Hinrichsen et al. 1998; Boberg 2005; Falkenmark and Lannerstad 2005). In Australia, demographic and population issues have long been relevant to urban water supply planning, as there are obvious links between population and water consumption. However, the practical

\footnotetext{
${ }^{+}$Address for correspondence: The Fenner School of Environment and Society, The Australian National University, Canberra ACT 0200, Australia. Email: Leonardo.Carroll@anu.edu.au.
} 


\section{Figure 1 Levels of water planning in Australia}

(a) High-level water plans: the Commonwealth and States/Territories

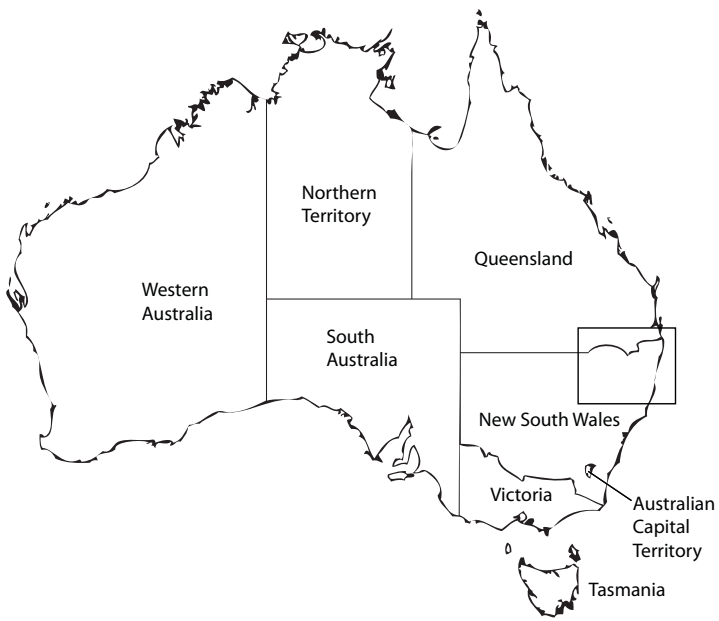

(b) Regional water plans: for example, catchment management areas (unbroken lines) and water management areas (dotted lines) in northern New South Wales

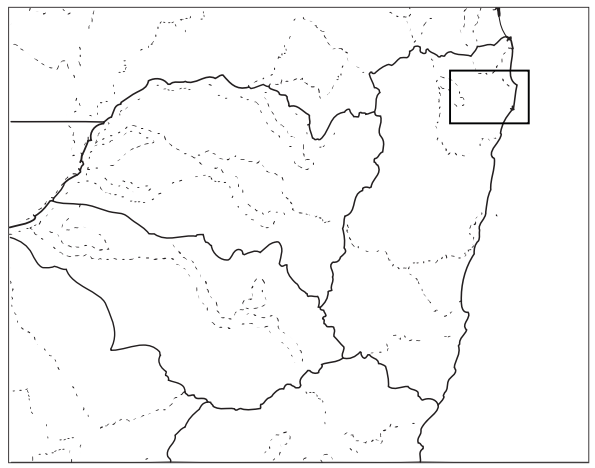

(c) Urban water supply planning: planning by Lismore Water, for example, covers the towns of Lismore, Modanville, Dunoon, Nimbin and Clunes

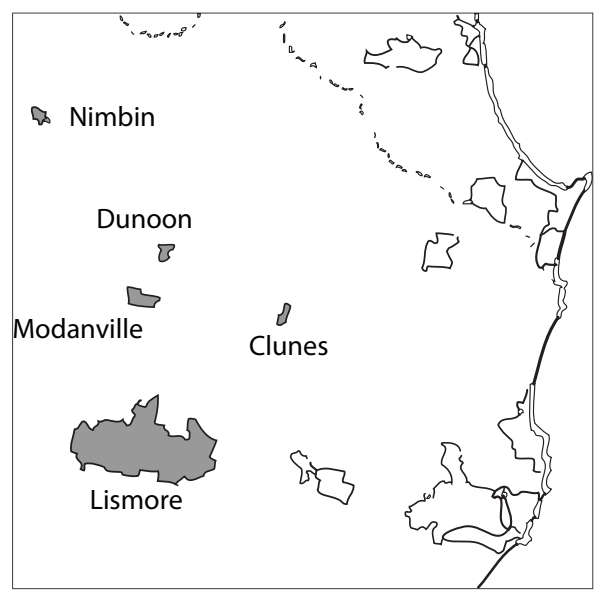


relevance of population issues to Commonwealth, state and regional water plans is less clear. Given the theoretical links between water and population, the significance of water resource management to Australia, and continuing population growth and change, this is a potential concern.

Table 1 summarizes characteristics of water resources in Australia. It shows that there are far more abundant water resources in Australia's north than in the more populated south, that most water consumption is for agriculture, and that minor quantities are used by households and industry.

Table 1 appears to show that available water resources are more than sufficient for human consumption. This is not the case, for several reasons. First, substantial proportions of available water need to be set aside for the well-being of the environment. Secondly, the availability of water is not uniform across each state and territory, either spatially (some localities are wetter than others) or temporally: in many parts of Australia, rainfall is seasonal and/or highly variable. Furthermore, Australia's human population is concentrated in towns and cities, mainly in the southeastern corner of the continent.

\section{Objectives and methods}

This paper explores ways in which demographic and population issues have been, or could be, taken into account by Australian water planners. It draws from content analysis of water plans, undertaken by the author as part of a continuing longer-term project. The extent to which water plans, and associated policy frameworks, consider population size, growth, territorial distribution and composition was investigated.

For the purposes of this paper, 'water plans' are defined as by Gentle and Olszak (2007: 59-60). Given that there are hundreds of such documents, ${ }^{1}$ it was not feasible to analyse the content of every individual plan in detail. Instead, this paper cites examples from different categories of plan, bearing in mind that the broader water planning policy landscape, as defined by the NWI and other legislative and policy frameworks, tends to shape plans within specific planning categories so that they share many similarities. The observations in the paper are therefore somewhat general: its purpose is to highlight key issues relating to demography, population and water planning, many of which may be worthy of further research.

The paper also draws from preliminary quantitative analysis of demographic data in selected water planning areas. These data were derived from the Australian Bureau of Statistics 2006 Basic Community Profiles (ABS 2007a) by concording census collection district data to water management area boundaries (OSDM 2003), using the MapInfo computer-based geographic information system (GIS).

The paper first describes how demography and population can be considered by urban water supply planners. Secondly, it presents an overview of how the newer Commonwealth, state and regional planning frameworks consider demography and population issues. Finally, it draws some conclusions about the status of demography and population in contemporary Australian water planning.

\section{Urban water supply planning and management}

In many parts of rural Australia, for example, rural New South Wales and Queensland, local councils are responsible for providing reticulated water to their citizens. 
농

ปี

$\frac{\pi}{\frac{0}{0}}$

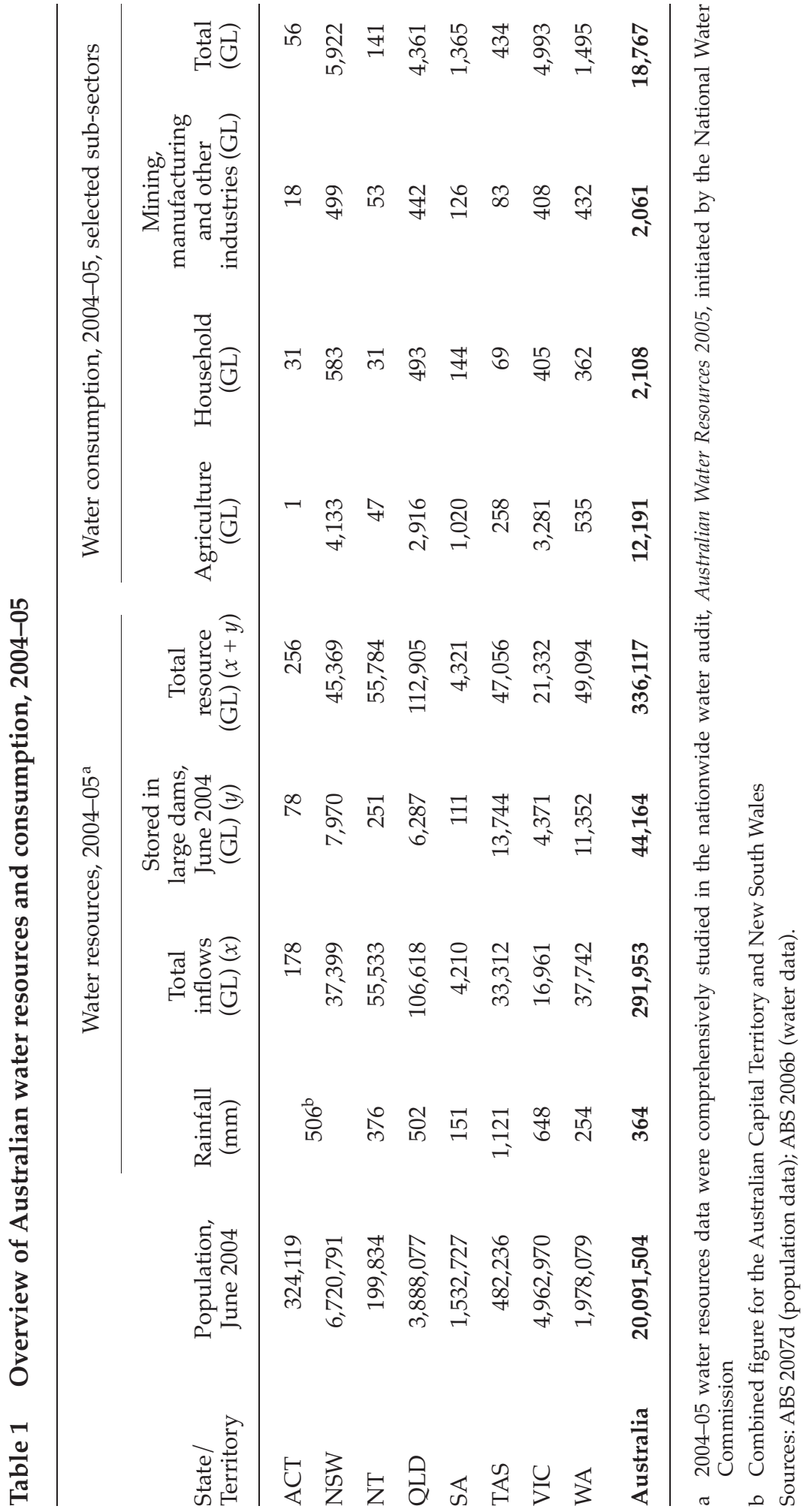


In larger cities, utilities such as Sydney Water, Melbourne Water, and ACTEW Corporation provide reticulated water. All prepare urban water supply plans.

Urban water supply plans are driven partly by state and territory government policies. Examples include the Australian Capital Territory government's Think Water Act Water report (ACT Government 2004a,b,c) and the New South Wales government's Metropolitan Water Plan (NSW Government 2006). Water utilities also take a practical interest in water supply planning, because they need to pay for, build and develop infrastructure, and deliver a secure supply to customers.

Urban water utilities' activities are monitored by government and industry bodies. For example in 2006, the Department of the Prime Minister and Cabinet commissioned Marsden Jacob and Associates to investigate the status of urban water utilities in Australia (Marsden and Pickering 2006a,b). Commonwealth and state governments have developed benchmarking frameworks (e.g. NWC 2006e,f); enacted policies to encourage 'integrated water cycle management', or IWCM (e.g. NWC 2007f); and published regular performance reports on urban and rural water utilities, such as the National Performance Reports (NWC et al. 2007a,b; 2008a,b) and the 2005-06 NSW Performance Monitoring Report (DWE 2007). These reports include extensive data on utilities' water storage capacity, the amounts supplied for different uses, the population to which water is supplied, assets owned by each utility, standards of customer service, and finances. The water utilities' peak body, the Water Services Association of Australia (WSAA), develops industry standards and codes of practice, commissions research, and reports on the industry's performance. The Australian Academy of Technological Sciences and Engineering (ATSE) has also commissioned studies on water supply (e.g. ATSE 2003).

There is insufficient space here to cover the details of water utilities' water planning methods. Many of the methods are described in documents such as Urban Water Demand Forecasting and Demand Management: Research Needs Review and Recommendations (White et al. 2003).

\section{Relevance of demography and population to urban water supply planning}

Demographic information is clearly relevant to urban water supply planning, as there are direct links between population and water consumption. Urban water plans typically take into account the current population and number of dwellings served, and then make projections for future supply, taking into account the projected population and number of dwellings, and anticipated future per capita water demand. There are many examples of the above approach, including the New South Wales 2006 Metropolitan Water Plan (NSW Government 2006: 4), the Victorian Our Water Our Future: Ballarat Regional Action Plan (DSE 2005), and the ACT's Think Water Act Water (ACT Government 2004a,b). Models of rainfall and temperature may also be incorporated (see Coombes et al. 2003). Estimates of future per capita water demand take into account the projected effect of water saving and recycling measures. For example, the NSW Government's 2006 Metropolitan Water Plan assumes water consumption of 426 litres per person per day in 2015, but notes that 400 litres per person per day is feasible, given successful demand reduction measures (NSW Government 2006: 14).

Demographic data for such analyses are readily available. Virtually all census data are available at the Statistical Local Area (SLA) and Local Government Area (LGA) level. This level of detail is more than sufficient for water supply analysis of major cities. In rural areas, data are sometimes required at the census collection district (CD) 
level, as rural SLAs and LGAs generally cover both urban regions and rural regions, which are usually not served by reticulated water. From the point of view of the water planner, the census provides more than sufficient demographic information at the CD level: the total population size, and the number and type of dwellings.

Water plans' future population and dwelling numbers are usually based on formal demographic projections, which take into account fertility, mortality and migration, as well as land use planning documents. For example in the ACT, Think Water Act Water takes into account the ACT Government's population projections (Chief Minister's Department 2004), Canberra Spatial Plan (ACT PLA 2004) and other landuse planning documents (e.g. ACT Government 2006).

\section{Areas where further demographic work could be useful}

Demographers already contribute to local water supply planning, through their contributions to local population counts, such as through the census, and to local population and household projections. These contributions to local water supply planning remain important under the new water policy reforms.

Together with other disciplines, particularly sociology, demographers could contribute to further research on the impact of finer-scale dwelling and household variables on urban water consumption. Recent studies have investigated finer-scale links between water consumption and demography (e.g. Loh and Coghlan 2003; Birrell et al. 2005; Troy and Randolph 2006; Troy et al. 2005, 2006).

Troy et al. $(2005,2006)$ analysed relationships between average water consumption per property calculated from water utilities' records, and household size and dwelling type (derived from ABS socio-economic profiles, cross-checked with other data sources including property databases), in a stratified sample of census collection districts in Sydney and Canberra. Troy and Randolph (2006) further investigated patterns of water consumption in Sydney, through a survey of 2,179 households and qualitative focus group research.

The findings of these studies suggest that sociological and demographic variables may be significant influences on water consumption, particularly in the context of water restrictions. For example, people who live in flats appear to exhibit different patterns of water use, and respond differently to water restrictions, from people in houses. People in wealthier areas also consume more water. Existing water supply plans do not always consider these details.

\section{Water planning at the national, state/territory and regional level}

\section{National and state/territory water planning}

Section 51 of the Australian Constitution, which describes the powers of the Commonwealth Government, makes no specific reference to water management. However, the Commonwealth has played an active role in the Murray-Darling Basin Scheme, the 1994 Council of Australian Governments (COAG) water reforms, and more recently, the National Water Initiative (NWI). The NWI commenced on 25 June 2004, when the Commonwealth and the governments of New South Wales, Victoria, Queensland, South Australia, the Australian Capital Territory and the Northern Territory signed the Intergovernmental Agreement on a National Water Initiative (COAG 2004). The agreement was subsequently signed by Tasmania and Western Australia. The purpose of the NWI is to promote '... a nationally compatible, market, regulatory and planning- 
based system of managing surface and groundwater resources for rural and urban use that optimises economic, social and environmental outcomes ...' (COAG 2004: paragraph 23). Specific sub-objectives, outcomes and actions are described in detail in the NWI agreement.

The NWI was followed, in January 2007, by a $\$ 10$ billion National Plan for Water Security (Commonwealth of Australia 2007), which was superseded in April 2008 by the new Rudd Government's \$12.9 billion, ten-year Water for the Future plan. This plan covers four priority areas: taking action on climate change, by improving monitoring of water resources and developing a plan for the Murray-Darling Basin; promoting efficient water use, including through upgrading irrigation infrastructure; securing water supplies for towns and cities; and promoting the environmental health of rivers, by buying back water entitlements from willing sellers (Commonwealth of Australia 2008). A legislative basis for many aspects of the plan is provided by the Water Act 2007 (Cth), which commenced on 3 March 2008.

At the national and state/territory level, two types of water plan are significant. First, the Commonwealth and state/territory governments are required to develop plans outlining how they will implement the NWI, in accordance with guidance provided by the National Water Commission (NWC 2005). The Commonwealth, states and territories have now completed these plans.

Secondly, some states and territories have prepared additional water plans which describe overall strategies and objectives for water management in that state or territory. Examples include the New South Wales State Water Management Outcomes Plan (NSW Government 2002), Western Australia's State Water Plan (Department of the Premier and Cabinet 2007) and Victoria's Our Water Our Future (DSE 2007).

\section{Regional water planning and management}

National and state/territory implementation of the NWI is underpinned by a variety of regional water planning and management processes. State and territory governments have established two main types of policy or legislative framework to manage water resources. First, they have frameworks designed to manage the allocation of water. For example, in New South Wales, the Water Management Act 2000 (NSW) provides for the creation of regional 'water sharing plans' whereby water resources in specific subregions (38 in February 2008) are allocated between different users, including town water utilities, irrigators, and industrial users. To gain access to water, water users are required to apply for various types of licence. Plans are administered by state or territory government agencies, for example, the Department of Water and Energy in New South Wales.

Secondly, frameworks have been developed to regulate and manage how water resources are used, and to what extent human activities such as industry and agriculture can affect water quality. Typically, such activities are managed at a catchment level, in accordance with 'catchment management plans'. These plans are developed and administered by a number of natural resource management organizations, with different institutional arrangements operating in each state and territory. In some jurisdictions, catchment management authorities are created under statute, such as the New South Wales Catchment Management Authorities Act 2003 (NSW); in others such as Queensland, catchment plans are developed by non-statutory organizations. For a more detailed description of regional catchment-based organizations, see Robins and Dovers (2007). 


\section{Monitoring and assessment of water resources}

For a demographer, an interesting aspect of national and state/territory water planning is the frameworks that have been developed to monitor and assess water resources and how they are used. These data frameworks inform national and state/territory water policy and planning. Some recent frameworks of this type are described below.

\section{National Land and Water Resources Audit}

In 1997, the National Land and Water Resources Audit (NLWRA) was established, under the National Heritage Trust, to collate data on the status of Australia's natural resources. As part of the Audit, the Government commissioned the Australian Water Resources Assessment 2000 (NLWRA 2001), which gathered primarily hydrological data for 325 surface-water management areas. It described the capacity of groundwater and surface water resources and the level of water extractions in different regions of the country.

\section{Australian Bureau of Statistics surveys and Water Accounts}

The Australian Bureau of Statistics (ABS) has, from time to time, conducted surveys of aspects of water use. For example, in 2003, ABS published results from an October 2002 survey on domestic water use in New South Wales (ABS 2003), which presented data on where water was sourced from, types of water-using appliances that were used, and use habits, for example, frequency of car washing and dishwasher use. Figures were presented for Sydney and for the balance of the state. In 2007, ABS published a follow-up report based on the October 2006 survey of domestic water and energy use in New South Wales (ABS 2007c). Data were presented along similar lines to the 2002 report, but with more detail on water use according to different dwelling types: flats, separate houses, etc.

In 2000, ABS published the first Water Account (ABS 2000), which described water use in the years 1993-94 to 1996-97. It was conducted in the context of policy initiatives of the time, including the 1994 COAG water reform framework, State of Environment Reporting (which was relatively new at the time), the NLWRA, and the Natural Heritage Trust program (ABS 2000: 2). The Water Account provided an overview of how water was used at the state and territory level, with some information on water use by specific industries. A second edition of the Water Account was published in 2004, covering the year 2000-01 (ABS 2004).

The third and most recent edition of the Water Account, covering 2004-05, was released in November 2006 (ABS 2006b). It was partly funded by the National Water Commission as a component of the Australian Water Resources 2005 project, described in more detail below, and was designed to complement the NWI. Data were collected in accordance with the United Nations System of Integrated Environmental and Economic Accounting (United Nations et al. 2003), taking into account advances in the theory and practice of water accounting.

The 2004-05 Water Account presented a wide range of data, which included overall water flows and stocks, broken down into key subcomponents such as rainfall, run-off, consumption, storage, allocations, entitlements, at the state/territory level; water consumption, by industry and state or territory; origin and use of distributed water, by industry and state or territory; data on the water supply industry, including numbers of water providers, and levels of infrastructure, by state or territory; use of 
water for agriculture, by activity such as livestock, vegetables, dairying, and state/ territory; use of water for mining and manufacturing, by activity and state/territory; household water use, by state/territory; and water access entitlements, allocations and trading, including volumes of water, by state/territory.

Much of the information was sourced from ABS surveys, including the 2004-05 Water Supply Survey, the 2004-05 Agricultural Survey, the 2004-05 Economic Activity Survey, the 2004-05 Electricity Generators Survey of Water Use, and the March 2005 Monthly Population Survey (ABS 2006b: 127)). The Water Account also drew on various state and territory reports on water resources and water utilities, and surveys conducted by industry associations including the Water Services Association of Australia and the Australian National Committee on Irrigation and Drainage (ABS 2006b: 128).

In future, Water Accounts are anticipated at four-yearly intervals, with the next account, for the years 2008-09, to be released in 2010.

In late 2007, the ABS released a special issue of its 'Australia's Environment' annual publication, Environment Issues and Trends 2007 - Special Issue on Water (ABS 2007b). This report presented an overview of water resources in Australia, with much information drawn from the 2004-05 Water Account, as well as overviews of other sectors of concern from an environmental perspective.

\section{Australian Water Resources 2005}

Paragraph 105(i) of the NWI Agreement stipulated that the NWC should prepare a baseline assessment of water resources. This has now been completed as the Australian Water Resources 2005 report (NWC 2006a; 2007a,c,d). The report was compiled by the NWC, with input from Australian governments at Commonwealth and state/ territory level, the Water Resources Observation Network (WRON) Alliance ${ }^{2}$, and other stakeholders. It covers the financial year 2004-05. Where possible it draws on existing data, particularly data compiled by agencies such as ABS and the Bureau of Rural Sciences.

Australian Water Resources (AWR) 2005 reported at two levels: first, a Level 1 Assessment at the state/territory level, and secondly, a more detailed Level 2 Assessment for selected water management areas $^{3}$ (WMAs) across Australia. These assessments covered three key areas:

Water availability. The Level 1 Assessment described water availability at the state/territory Level, while the Level 2 Assessment described water availability for 51 selected WMAs around Australia.

Water use. The assessments drew upon other data sets and reports including the Water Account 2004-05 (ABS 2006b), Water Use on Australian Farms (ABS 2006f), Experimental Estimates of Regional Water Use, Australia, 2004-05 (ABS 2006c), and Water Access Entitlements, Allocation and Trading, 2004-05 (ABS 2006d).

River and wetland health. The assessments proposed a National Framework for the Assessment of River and Wetland Health, based around six key components: catchment disturbance, physical form, hydrological disturbance, water quality and soils, fringing zone, and aquatic biota.

The Level 2 Assessment included an 'Integration of Results' section (NWC 2007a: 57), reporting on the sustainability of water use across 51 selected WMAs, according to three indicators. First, it reported on the level of water use for a given WMA, defined as the ratio between total diversions and extractions from a water sys- 
tem, and the total sustainable yield ${ }^{4}$ of that system. Secondly, it reported on consumptive use as a proportion of inflows, where the inflows comprise surface water runoff, groundwater recharge, and transfers into the system (NWC 2007a: 62). Thirdly, it reported on consumptive use as a proportion of water resource, where the total water resource comprises total inflows as defined above, plus the volume of water stored at the start of the year (NWC 2007a: 62).

The assessments in AWR2005 have provided an invaluable snapshot of the state of Australia's water resources, and their levels of use, notwithstanding the fact that the data were specifically for 2004-05, and therefore not necessarily representative of longer-term conditions. AWR2005 acts as a baseline for future assessments.

\section{Other water data resources}

The Commonwealth Government is committed to future monitoring and reporting of water resources. The planned Australian Water Resources Information System (AWRIS) will be a key resource for future water managers. According to documents released in early 2007, AWRIS

... will provide a comprehensive, credible, open view of Australia's water resources data and information. It will allow users to review and investigate this data, understand the data in context, and bigger picture details about the data. AWRIS will help further (and add value to) the discussion about water (NWC 2007b: 6; see also NWC 2006b,c,d).

AWRIS will build on the data transfer standards and protocols being developed by the Executive Steering Committee for Australian Water Resources Information (ESCAWRI), a committee under the Natural Resources Management Ministerial Council $^{5}$ (NWC 2007a: 77). It will complement other programs including the Water 2010 project, which will capture information on water balances, considering the implications of land use, population, climate and other variables (BRS 2007); the Australian Water Data Infrastructure Project, which aims to develop a network of hydrological databases (BRS 2008); and the Water Resources Observation Network, which will provide real-time access to a number of water information sources (CSIRO et al. 2008). The relationship between these programs is described in ESCAWRI (2007).

\section{Relevance of demography and population}

Demography and population have relatively insignificant effects on overall national and state/territory water use. As shown in Table 1, agriculture uses approximately two-thirds of Australia's water. However, as most of Australia's agricultural production is for export, there is no direct link between Australian demography and agricultural water use. Household water consumption, which is directly linked to population size, accounts for approximately one-ninth of the total. The Australian Capital Territory, where household water use made up more than half the total water consumption in 2004-05 (see Table 1), is perhaps the only example of a state or territory where demography has a significant impact. Yet the ACT is essentially a citystate, covered by urban water supply planning by ACTEW Corporation.

Perhaps because of this, references to demographic and population issues in Commonwealth water policy are infrequent. The NWI document does not appear to mention population or demography at all. ${ }^{6}$ The AWR2005 report is also largely silent on population issues. It refers to population mainly in the context of capital city water use, a context where population size, numbers of connected properties 
and per capita consumption have clear implications for total water consumption (e.g. NWC 2007a: 31-32). Furthermore, most of the information in the ABS Water Account 2004-05, much of which was drawn upon in AWR2005, was obtained from industry surveys, water providers, and reports from state and territory governments (ABS 2006b: 126-132). Unlike many other ABS datasets, therefore, it is not easily linked to population data, such as the census. Where population figures are included, for example in Table 1.2 (ABS 2006b: 8) they appear to be for completeness rather than understanding other data.

Some state and territory water plans appear to take more explicit account of population issues, for example, the plans developed by the Victorian Government (DSE 2007) and Western Australian Government (Department of the Premier and Cabinet 2007). These plans focus on how population growth will affect water demand in specific regions, usually major urban areas. They make broad policy statements in response to anticipated water shortfalls, such as promoting water-demand management, recycling, or augmenting water supply through desalination.

One of the few areas where state and territory water planning legislation mentions population issues is in the context of local water utilities' access to water for town supply. For example, under the Water Management Act 2000 (NSW), water allocations for local water utilities are to take into account population issues. Section 13(3) notes that the quantity of water to be covered by a licence will be linked to, inter alia, population size. Section 66(3) suggests that the Minister may vary licences for local water utilities at the end of each five-year period, to reflect population change. Section 66(4) stipulates that the Minister may, at any time upon application by the utility, increase a local water utility's entitlement to water to reflect population growth. As discussed previously in this paper, it is urban water supply planners who consider in detail the demographic and population variables underpinning these entitlements.

Yet demographic data are certainly useful to Commonwealth, state and regional water planners. The AWR2005 report describes how various WMAs are suffering degrees of water stress (NWC 2007a: 57-75). It is implicit that something needs to be done about this. The NWI delegates responsibility for the problem to the states and territories, stipulating that signatories should implement effective water-access entitlements and planning frameworks, ${ }^{7}$ and if necessary, address currently overallocated or overused systems in accordance with agreed implementation programs. ${ }^{8}$ The NWI also advocates the implementation of water markets and trading, ${ }^{9}$ which will ideally reduce pressures on the environment through market-based accounting for environmental externalities. ${ }^{10}$ In the context of this policy framework, national and state/territory water planners are particularly concerned about the impacts of water policy (and planning) reform on populations. The NWI recognizes the importance of 'socio-economic analysis' in water planning ${ }^{11}$ in the context of considering trade-offs when allocating water to different uses. It is implicit that implementation of the NWI will result in changes to the availability of water for different, particularly agricultural, applications, and that these changes may have socio-economic impacts which need to be considered.

\section{Areas where further demographic work could be useful}

Demographers can contribute to water policy and planning reforms by helping gather demographic and population data in a number of areas. Some of this work could be built into existing frameworks for water data, such as the ABS water surveys and 
accounts, AWRIS, and future water resources assessments based on Australian Water Resources 2005. Work could also be undertaken separately. There is a particular need to build knowledge of population issues at the regional water planning level, as it is there that much of the practical implementation of the NWI will take place. Some possible areas of focus are set out below.

\section{Understanding who is affected by different water plans}

Table 2 presents some water consumption and population characteristics for selected Australian WMAs. Each of these WMAs is subject to a relatively high degree of water stress, according to criteria set by AWR2005 (NWC 2007a: 66). As for the states and territories overall, most water is used for agriculture. Relatively insignificant amounts are consumed by households, except in the WMAs which include capital cities (Adelaide, Perth, and Sydney). Alice Springs is a special and unusual case: water stress there is significantly affected by the large numbers of tourists that visit the area.

Each of the WMAs in Table 2 is governed by regional water plans: water sharing and/or catchment plans. In addition, many of the urban areas within each WMA are covered by urban water supply plans. Yet little information appears to be available on who lives in WMAs, and who is affected by different water planning instruments, with the exception of urban water supply plans, within each WMA. While the demography of water users, particularly outside urban areas, may not be highly relevant to water consumption, it may well be relevant to broader political considerations underpinning water policy, as these water users will clearly be stakeholders in the process. Particular attention needs to be given to the demography of indigenous people's needs, which are highlighted in the NWI. ${ }^{12}$

Table 2 includes some preliminary demographic information, relating to urban and rural population sizes. It should be relatively straightforward to obtain further information. This could be achieved partly through manipulation of ABS census data, which are available at a range of geographic scales, including the Census Collection District (CD) scale, and from this year onwards, at an even smaller 'mesh block' level. While errors will always arise when concording data between disparate geographic areas (Singh and Ahmed 2007), sufficiently detailed data for water management areas or sub-catchments should not be difficult to derive. Further analysis of water planning instruments, such as water sharing plans and catchment management plans, and how they relate to water users, would also be required.

\section{Understanding who uses water}

There may be a need for better understanding of the characteristics of water users, not only urban households whose data should be collected by urban water suppliers, but also agricultural and industrial users. Such users may be affected by future water shortages.

Some data sources already exist. These include data on water use by industry in the ABS Water Account; data on agricultural water use in the ABS Agricultural Census; the report Water Use on Australian Farms, which draws upon data collected in the Agricultural Census, and which presents estimates of water used for different crops or purposes by state/territory (ABS 2006f); and the report Characteristics of Australia's Irrigated Farms 2000-01 through 2003-04 (ABS 2006g), which presented data on farms that use and trade irrigation water, drawing upon the 2000-01 Agricultural Census, 
the 2001-02, 2002-03 and 2003-04 Agricultural Surveys, the 2002 Land Management and Salinity Survey and the 2002-03 Water Survey Agriculture.

One potential problem with these data sources is that because they are based on surveys rather than on census data, it is difficult to correlate findings with specific populations, particularly in small areas such as water management areas or catchments. Hence, it is possible from the existing data to make general observations about patterns of water use for agriculture, but not necessarily for specific regions.

Some of the issues associated with deriving small-area data from surveys were described in two research papers released by the ABS in 2006, which described methodologies for calculating regional (small-area) estimates of water use. The first (ABS 2006e) applied state water use averages from the 2000-01 Water Account and Agricultural Census to SLA-level data, using a technique referred to as a 'broad area ratio estimator with auxiliary information' (ABS 2006e: 6). This method estimated water use for small areas by calculating a mean application rate (of water) for each state and crop type, taking into account the total amount of water used in each state for a given crop, from the Water Account, and the area of land used for that crop, from the Agricultural Census, and then applying this mean application rate to small areas, taking into account the known hectares of crop within the given local area. The report noted a number of errors inherent in the method, described as sampling errors, nonsampling errors, model specification errors, and area-weighting error.

A revised method was developed as part of the AWR2005 project, and presented in the second report (ABS 2006c). In the revised method (ABS 2006c: 6-7), profiles were developed for each surface-water management area, which described the businesses, individuals and organizations operating within that area, stratified by industry and employment size. Agricultural water use was calculated by a method derived from the first paper. Household water consumption was derived from the ABS Water Supply Survey and Monthly Population Survey. Total water consumption for each water-management area was then calculated from the above estimates.

There may be scope for these methods, or improved versions thereof, to be applied to specific water-management areas or catchments around Australia, to support implementation of the NWI or future incarnations of the AWR2005 assessment.

\section{Understanding who will be affected by water markets and trading}

Water availability and price will be affected by water markets and trading schemes, introduced under the NWI. Changes in water availability and price will have definite implications for water users, with potential broader social implications if users are forced to change industries or location. The Commonwealth Government has already commissioned investigations of the social impacts of water trading (e.g. Frontier Economics et al. 2007). Together with other disciplines such as economics and sociology, there is scope for demographers to contribute to further work in this area.

There is also relatively little information on who is trading water. Some data were collected by ABS (2006d) in its report on water access entitlements, allocating and trading in 2004-05, catchment management authority areas in NSW, and surfacewater management areas. However, because the data were synthesized from other sources including government registers and surveys, it is difficult to correlate the trading data with specific populations. Some water planners, for example catchmentmanagement authorities, might benefit from a better understanding of how the trading data match up with people in their area. 


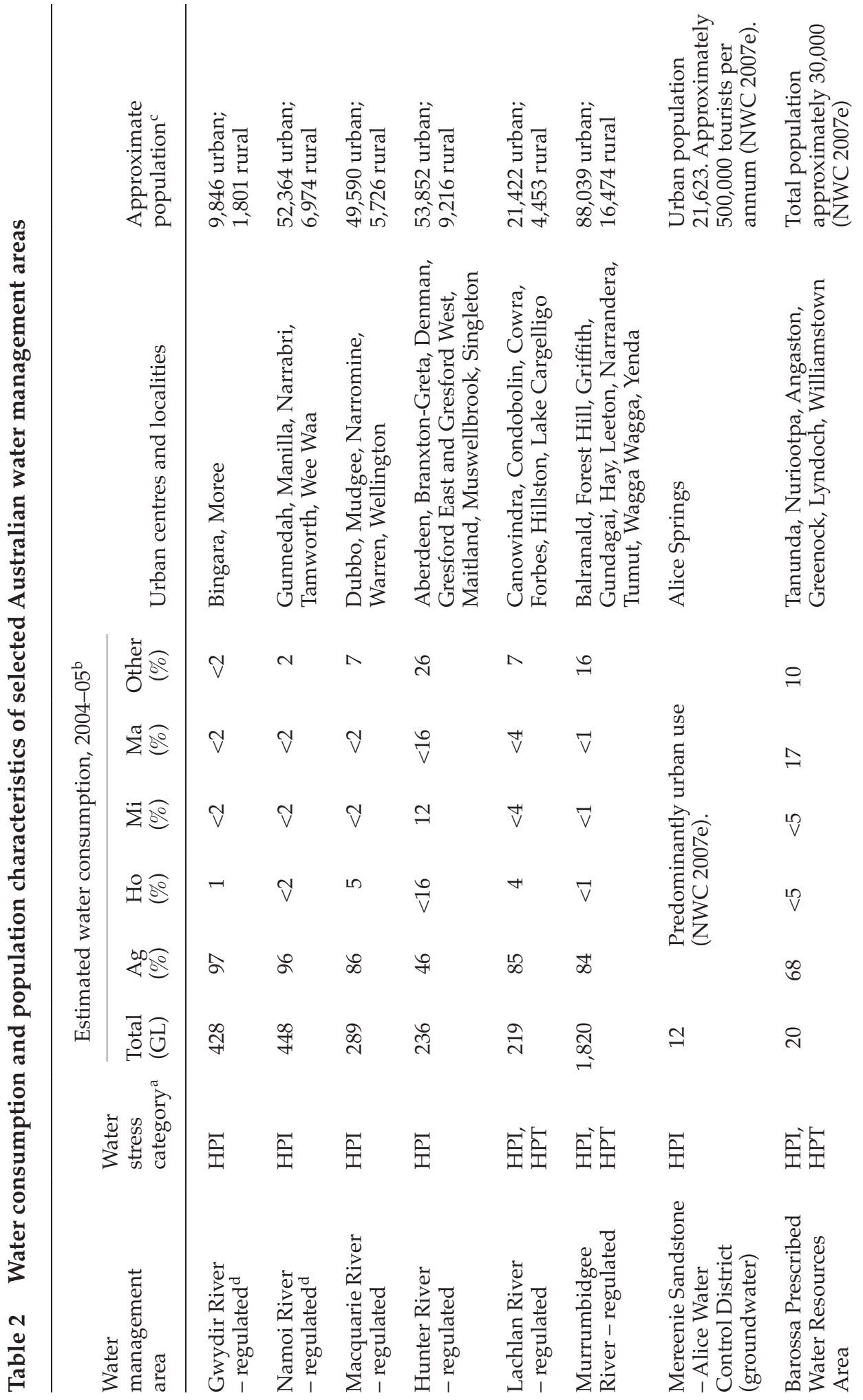




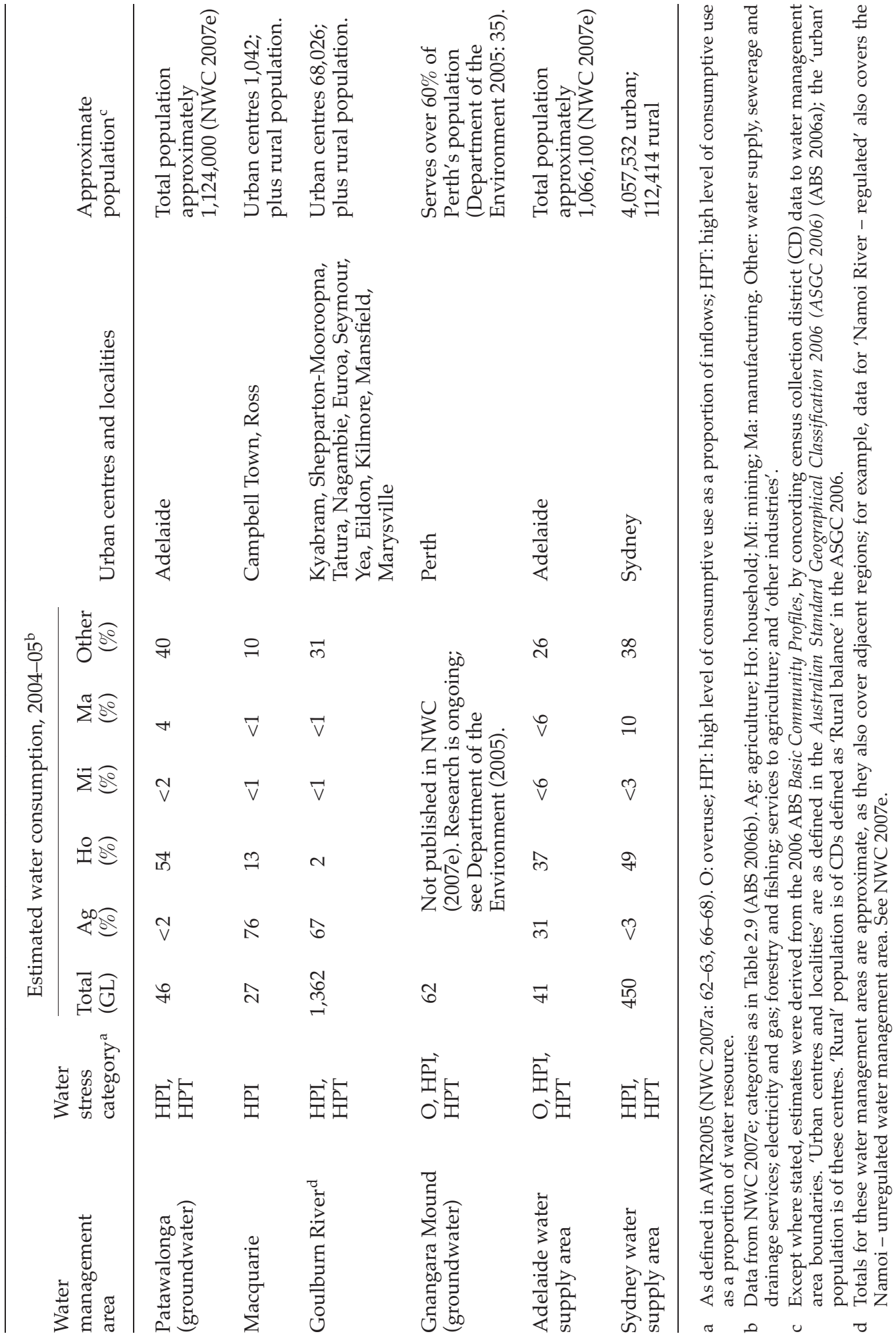




\section{Groundwater}

A significant proportion of Australia's water resources is found underground. Approximately 60 per cent of Australia is totally dependent on groundwater and in a further 20 per cent of the country, groundwater is the dominant water supply (Pigram 2006: 25). In many parts of Australia, population pressures are putting stress on groundwater reserves. While some work has already been done to assess the impact of population growth on groundwater, for example, in the Yass Valley (Franklin and Parker 2004), there appears to be a need for further work in this area. Such work would feed into regional and local water-supply plans.

\section{Conclusion}

Population issues are relevant to Australian water planners, particularly those who deal with highly water-stressed areas and areas with rapid population growth. The continuing water policy reform process, centred on the NWI, provides new opportunities for water planners to consider demographic and population issues. As the current water reforms have only been under way since 2004, many aspects of water planning, and its possible links to population, are still being developed.

This paper has highlighted some areas in which demography, together with other disciplines, can contribute to water planning in Australia. The significance of demographic data to water planners differs depending on whether rural or urban areas are considered. In urban areas, particularly the larger cities, water pressures are directly associated with population growth. Demographers can contribute to demand-management policy, by helping build a finer-scale understanding of water consumption behaviour. In most rural areas, the numbers of people are simply too insignificant to have a significant impact on water use, except in specific localities where overuse of local water resources, especially groundwater, can lead to localized water stress. For rural water planners, population data can be useful for other reasons. Demographers can help develop understanding of who is affected by water planning regimes, who uses water, and who might be affected by new water policies, such as the development of water markets and trading schemes.

One issue that may warrant further investigation is the extent to which regional, national and state water planners get involved with local councils and land-use planners, and how such interactions can most effectively take place. It is in the context of land-use planning that population issues are considered most directly. Demographic and population issues may therefore be especially significant to water planners who have stronger links to land-use planning. It may also be useful to consider experiences from other parts of the world with similar water and population issues, such as Southern Europe, the Middle East, South Africa, and parts of North America. While Australia's NWI is arguably very advanced in its approach to water planning, policy frameworks such as the European Union's Water Framework Directive might provide useful lessons.

\section{Notes}

1 Based on continuing analysis by the author, as part of a longer-term research project.

2 The Water Resources Observation Network (WRON) Alliance is an informal group of agencies that have agreed to work together to revolutionize the collection, utility, and pres- 
entation of water-resources information. The agencies include CSIRO, Bureau of Rural Sciences, Bureau of Meteorology, Geoscience Australia, eWater CRC, Murray-Darling Basin Commission, the National Land and Water Resources Audit, ABS, Sinclair Knight Merz, Kisters Pty Ltd, and NGIS Australia. See <http:/ / wron.net.au/progress/ stage2-alliance. html>.

3 Water Management Areas have been defined by a number of state and territory watermanagement agencies for the purpose of water resources reporting. Their boundaries sometimes follow natural features, such as catchment boundaries, and sometimes follow political boundaries.

4 There is continuing debate over the definition of 'sustainable yield'. There is currently no standardized method for determining sustainable yield, and each state or territory defines it differently. For the purposes of the AWR2005 report, 'sustainable yield' was defined for each water management area in accordance with data provided by the relevant state or territory.

5 The Natural Resources Management Ministerial Council comprises Commonwealth, state and territory ministers, plus New Zealand Government ministers, responsible for primary industries, natural resources, environment and water policy. It is the peak government forum for consultation and co-ordination on natural resource management.

6 Based on a simple word search of the NWI document.

7 NWI, paragraphs 25-40.

8 NWI, paragraphs $41-45$.

9 NWI, paragraphs 58-72.

10 NWI, paragraph 73.

11 In accordance with NWI Agreement paragraph 36, and Schedule E.

12 Indigenous needs are mentioned in NWI paragraphs 25(ix) and 52-54, as well as in the guidelines for water planning in Schedule E.

\section{References}

Australian Academy for Technological Sciences and Engineering (ATSE). 2003. Water - The Australian Dilemma. <http://www.atse.org.au/index.php?sectionid=627>. Melbourne. Accessed 12 July 2007.

Australian Bureau of Statistics (ABS). 2000. Water Account, Australia, 1993-94 to 1996-97. Cat. No. 4610.0. Canberra.

Australian Bureau of Statistics (ABS). 2003. Domestic Water Use, New South Wales, October 2002. Cat. No. 4616.1. Canberra.

Australian Bureau of Statistics (ABS). 2004. Water Account, Australia, 2000-01. Cat. No. 4610.0. Canberra.

Australian Bureau of Statistics (ABS). 2006a. Statistical Geography Volume 1: Australian Standard Geographical Classification (ASGC), July 2006. Cat. No. 1216.0. Canberra.

Australian Bureau of Statistics (ABS). 2006b. Water Account, Australia, 2004-05. Cat. No. 4610.0. Canberra.

Australian Bureau of Statistics (ABS). 2006c. Experimental Estimates of Regional Water Use, Australia, 2004-2005. Cat. No. 4610.0.55.002. Canberra.

Australian Bureau of Statistics (ABS). 2006d. Water Access Entitlements, Allocations and Trading, 2004-05. Cat. No. 4610.0.55.003. Canberra.

Australian Bureau of Statistics (ABS). 2006e. A Methodology for Estimating Regional Agricultural Water Use. Cat. No. 4616.0.55.001. Canberra.

Australian Bureau of Statistics (ABS). 2006f. Water Use on Australian Farms. Cat. No. 4618.0. Canberra.

Australian Bureau of Statistics (ABS). 2006g. Characteristics of Australia's Irrigated Farms, 2000 01 to 2003-04. Cat. No. 4623.0. Canberra. 
Australian Bureau of Statistics (ABS). 2007a. 2006 Census of Population and Housing Datapack: Basic Community Profile, Release 2. Cat. No. 2069.0.30.001. Canberra.

Australian Bureau of Statistics (ABS). 2007b. Australia's Environment Issues and Trends, 2007: Special Issue: Water. Cat. No. 4613.0. Canberra.

Australian Bureau of Statistics (ABS). 2007c. Domestic Water and Energy Use, New South Wales, October 2006. Cat. No. 4621.1. Canberra.

Australian Bureau of Statistics (ABS). 2007d. National Regional Profiles. <http:/ / www.abs.gov. au/AUSSTATS/abs@.nsf/nrpbygeogtype?openview\&restricttocategory=Main\%20Areas \&Expand $=1 \&>$. Canberra. Accessed 1 March 2008.

ACT Planning and Land Authority (ACTPLA). 2004. The Canberra Spatial Plan. Canberra.

Australian Capital Territory (ACT) Government. 2004a. Think Water, Act Water. Volume 1. Strategy for Sustainable Water Resource Management in the ACT. Canberra.

Australian Capital Territory (ACT) Government. 2004b. Think Water, Act Water. Volume 2. Explanatory Document. Canberra.

Australian Capital Territory (ACT) Government. 2004c. Think Water, Act Water. Volume 3. State of the ACT's Water Resources and Catchments. Canberra.

Australian Capital Territory (ACT) Government. 2006. The Government's Land Supply Strategy, 2006-07 to 2010-11. Canberra.

Birrell, B., V. Rapson and T. F. Smith. 2005. Impact of Demographic Change and Urban Consolidation on Domestic Water Use. Melbourne: Water Services Association of Australia.

Boberg, J. 2005. Liquid Assets: How Demographic Changes and Water Management Policies Affect Freshwater Resources. Santa Monica: RAND Corporation.

Bureau of Rural Sciences (BRS). 2007. Water 2010: National Rural Water Balance Information for Policy and Planning. <http://www.daff.gov.au/brs/climate-impact/water-2010>. Canberra. Accessed 1 August 2007.

Bureau of Rural Sciences (BRS). 2008. The Australian Water Data Infrastructure Project. <http:/ / www.daff.gov.au/brs / water-sciences/ground-surface/ awdi-project $>$. Canberra. Accessed 20 May 2008.

Chief Minister's Department. 2004. Population Projections for Canberra Suburbs and Districts 2004 to 2014. Canberra.

Council of Australian Governments (COAG). 2004. Intergovernmental Agreement on a National Water Initiative. Canberra.

Commonwealth of Australia. 2007. A National Plan for Water Security - 25 January 2007. Canberra.

Commonwealth of Australia. 2008. Water for the Future: The Australian Government's Plan for Water. Canberra.

Coombes, P. J., M. A. Thyer, A. Frost, G. Kuczera and I. Grimster 2003. Development of stochastic multisite rainfall and urban water demand for the central coast region of New South Wales. Paper presented at 28th International Hydrology and Water Resources Symposium, Wollongong, 10-14 November.

CSIRO, Bureau of Rural Sciences, Bureau of Meteorology, Geoscience Australia, eWater CRC, Murray-Darling Basin Commission, National Land and Water Resources Audit, Australian Bureau of Statistics, Sinclair Knight Merz, Kisters Pty Ltd and NGIS Australia. 2008. Water Resources Observation Network. <http:/ / www.wron.net.au/index.html>. Accessed 20 May 2008.

Department of the Environment. 2005. Managing a Sustainable Future for the Gnangara Groundwater Resources: Gnangara Mound - Stakeholder Issues and Perspectives. Perth.

Department of the Premier and Cabinet. 2007. State Water Plan 2007. Perth.

Department of Sustainability and Environment (DSE). 2005. Our Water Our Future: Ballarat Regional Action Plan. Melbourne.

Department of Sustainability and Environment (DSE). 2007. Our Water Our Future: The Next Stage of the Government's Water Plan. Melbourne. 
Department of Water and Energy (DWE). 2007. 2005-06 Water Supply and Sewerage: NSW Performance Monitoring Report. Sydney.

Executive Steering Committee for Australian Water Resources Information (ESCAWRI). 2007. Relationship between WRON, AWRIP and AWRIS. Canberra.

Falkenmark, M., J. Kijne, B. Taron, G. Murdoch, M. Sivakumar and E. Craswell. 1997. Meeting water requirements of an expanding world population [and discussion]. Philosophical Transactions: Biological Sciences 352(1356): 929-936.

Falkenmark, M. and M. Lannerstad. 2005. Consumptive water use to feed humanity - curing a blind spot. Hydrology and Earth System Sciences 9: 15-28.

Falkenmark, M. and C. Widstrand. 1992. Population and water resources: a delicate balance. Population Bulletin 47(3).

Franklin, J. and B. Parker. 2004. Yass Snapshot on Sustainability: A Project to Assess Sustainability of Land and Water Management in the Yass River Catchment. Sydney: NSW Department of Infrastructure, Planning and Natural Resources.

Frontier Economics, Tim Cummins and Associates, A. Watson, E. Barclay and I. Reeve. 2007. The Economic and Social Impacts of Water Trading: Case Studies in the Victorian Murray Valley. Report for the Rural Industries Research and Development Corporation, National Water Commission and Murray-Darling Basin Commission. Canberra: Commonwealth of Australia.

Gentle, G. and C. Olszak. 2007. Water planning: principles, practices and evaluation. Pp. 59-71 in S. Dovers and K. Hussey (eds), Managing Water for Australia: The Social and Institutional Challenges. Melbourne: CSIRO Publishing.

Hinrichsen, D., B. Robey and U. D. Upadhyay. 1998. Solutions for a Water-Short World. Population Reports, Series M, No. 14. Baltimore: Johns Hopkins School of Public Health.

Loh, M. and P. Coghlan. 2003. Domestic Water Use Study in Perth, Western Australia, 1998-2001. Perth: Water Corporation of Western Australia.

Marsden, J. and P. Pickering. 2006a. Securing Australia's Urban Water Supplies: Opportunities and Impediments. Discussion paper prepared for the Department of the Prime Minister and Cabinet. Melbourne: Marsden Jacob Associates.

Marsden, J. and P. Pickering. 2006b. Securing Australia's Urban Water Supply: Research Notes for Selected Case Studies. Discussion paper prepared for the Department of the Prime Minister and Cabinet. Melbourne: Marsden Jacob Associates.

National Land and Water Resources Audit (NLWRA). 2001. Australian Water Resources Assessment 2000. <http://www.anra.gov.au/topics/water/pubs/national/water_contents. html>. Canberra. Accessed 15 March 2008.

National Water Commission (NWC). 2005. Guidance on the Preparation of Implementation Plans for the National Water Initiative. Canberra.

National Water Commission (NWC). 2006a. Australian Water Resources 2005: A Baseline Assessment of Water Resources for the National Water Initiative. Level 1 Assessment: Key Findings. Canberra.

National Water Commission (NWC). 2006b. Australian Water Resources 2005: A Baseline Assessment of Water Resources for the National Water Initiative. Level 2 Assessment. Australian Water Resources Information System: Implementation and Investment Plan. Canberra.

National Water Commission (NWC). 2006c. Australian Water Resources 2005: A Baseline Assessment of Water Resources for the National Water Initiative. Level 2 Assessment. Australian Water Resources Information System: System Architecture. Canberra.

National Water Commission (NWC). 2006d. Australian Water Resources 2005: A Baseline Assessment of Water Resources for the National Water Initiative. Level 2 Assessment. Australian Water Resources Information System: User Requirements. Canberra.

National Water Commission (NWC). 2006e. Draft National Benchmarking Framework: Performance Reporting Model for Urban Water Utilities. Canberra.

National Water Commission (NWC). 2006f. National Benchmarking Framework: Draft Performance Reporting Model for Rural Water Delivery Agencies. Canberra. 
National Water Commission (NWC). 2007a. Australian Water Resources 2005: A Baseline Assessment of Water Resources for the National Water Initiative. Key Findings of the Level 2 Assessment. Summary Results. Canberra.

National Water Commission (NWC). 2007b. Australian Water Resources 2005: A Baseline Assessment of Water Resources for the National Water Initiative. Level 2 Assessment. Australian Water Resources Information System: Executive Overview. Canberra.

National Water Commission (NWC). 2007c. Australian Water Resources 2005: A Baseline Assessment of Water Resources for the National Water Initiative. Level 2 Assessment. Water Availability Theme: National Perspective. Canberra.

National Water Commission (NWC). 2007d. Australian Water Resources 2005: A Baseline Assessment of Water Resources for the National Water Initiative. Level 2 Assessment. Water Availability Theme: Regional Water Balances. Canberra.

National Water Commission (NWC). 2007e. Australian Water Resources 2005: Regional Water Resource Assessments. <http:/ / www.water.gov.au/RegionalWaterResourcesAssessments / index.aspx?Menu=Level1_7>. Canberra. Accessed 15 March 2008.

National Water Commission (NWC). 2007f. Institutional and Regulatory Models for Integrated Water Cycle Management - Issues and Scoping Paper. Canberra.

New South Wales (NSW) Government. 2002. State Water Management Outcomes Plan Order 2002 (NSW). Sydney.

New South Wales (NSW) Government. 2006. 2006 Metropolitan Water Plan. Sydney.

NWC, WSAA and Parties to the NWI. 2007a. National Performance Report 2005-06: Major Urban Water Utilities. Report by the National Water Commission, Water Services Association of Australia, and the Parties to the National Water Initiative. Melbourne: Water Services Association of Australia.

NWC, WSAA and Parties to the NWI. 2007b. National Performance Report 2005-06: Non-Major Urban Water Utilities. Report by the National Water Commission, Water Services Association of Australia, and the Parties to the National Water Initiative. Melbourne: Water Services Association of Australia.

NWC, WSAA and Parties to the NWI. 2008a. National Performance Report 2006-07: Rural Water Service Providers. Report by the National Water Commission, Water Services Association of Australia, and the Parties to the National Water Initiative. Melbourne: Water Services Association of Australia.

NWC, WSAA and Parties to the NWI. 2008b. National Performance Report 2006-07: Urban Water Utilities. Report by the National Water Commission, Water Services Association of Australia, and the Parties to the National Water Initiative. Melbourne: Water Services Association of Australia.

Office of Spatial Data Management (OSDM). 2003. Australian Surface Water Management Areas 2000 - Digital Boundaries. Copyright Commonwealth of Australia 2003. Canberra.

Pigram, J. J. 2006. Australia's Water Resources: From Use to Management. Melbourne: CSIRO Publishing.

Robins, L. and S. Dovers. 2007. Community-based NRM boards of management: are they up to the task? Australasian Journal of Environmental Management 14(2): 111-122.

Singh, I. and M. Ahmed. 2007. Use of Census Information and Natural Resource Management in NSW. Sydney: NSW Department of Natural Resources.

Smith, D. I. 2003. Water resources management. Pp. 53-89 in S. Dovers and S. Wild River (eds), Managing Australia's Environment. Sydney: Federation Press.

Troy, P., D. Holloway and K. Nissen. 2006. Domestic Water Consumption in the ACT: A Review of Water Consumption in the ACT Including an Exploration of the Demand Management Initiatives Taken to Reduce Water Consumption. Canberra: ANU College of Science, Australian National University.

Troy, P., D. Holloway and B. Randolph. 2005. Water Use and the Built Environment: Patterns of Water Consumption in Sydney. Research Paper No. 1. Sydney: City Futures Research Centre, Faculty of the Built Environment, University of New South Wales. 
Troy, P. and B. Randolph. 2006. Water Consumption and the Built Environment: A Social and Behavioural Analysis. Sydney: City Futures Research Centre, Faculty of the Built Environment, University of New South Wales.

United Nations, European Commission, International Monetary Fund, Organization for Economic Cooperation and Development and World Bank. 2003. Integrated Environmental and Economic Accounting 2003. Final draft circulated for information prior to official editing.

White, S., J. Robinson, D. Cordell, M. Jha and G. Milne. 2003. Urban Water Demand Forecasting and Demand Management: Research Needs Review and Recommendations. Melbourne: Water Services Association of Australia. 